\title{
Endometrial Cytological Evaluations in Repeat Breeding Crossbred Cows
}

\author{
Anil Kumar Pandey ${ }^{1 *}$, Utsav Sharma ${ }^{1}$ and Sharad Kumar ${ }^{2}$
}

${ }^{1}$ Division of Veterinary Gynaecology and Obstetrics, ${ }^{2}$ Division of Teaching Veterinary Clinical Complex, Faculty of Veterinary Sciences and Animal Husbandry, R. S. Pura, Sher-e-Kashmir University of Agricultural Sciences and Technology of Jammu, J\&K, India

*Corresponding author: anil_p8@yahoo.com

Received: $10-04-2020$

Revised: 20-06-2020

Accepted: $28-07-2020$

\begin{abstract}
Endometrial cytological study using cytobrush technique was conducted on 80 crossbred cows under field condition to evaluate the prevalence of subclinical endometritis. Animals were grouped in three groups, the group-I ( $=20)$ : normal cyclic cows having no previous repeat breeding history and had clear stringy vaginal mucus discharge on estrus; the group-II $(n=40)$ : repeat breeding cows, had clear stringy vaginal mucus discharge on estrus; and the group-III $(n=20)$ : endometritic cows, had turbid vaginal mucus with visible white flakes. The endometrial cell cytology was performed using modified cytobrush technique. All animals with clear stringy cervico-vaginal mucus discharge (group-I and group-II) were inseminated without any treatment. The mean polymorphonuclear (PMN) cell \% in the normal cyclic, repeat breeding and endometritis group of cows were $2.01 \pm 0.25,5.36 \pm 0.39,11.82 \pm 0.82$ with $1(5 \%), 26(65 \%)$ and $20(100 \%)$ animals having $>4 \%$ PMN cells in the respective group of cows. The overall conception rate in normal cyclic group was $95 \%$ after 3 inseminations while in the repeat breeding group it was $10 \%$. Cows with turbid discharge (group-III) were given $20 \mathrm{ml}$ liquid Levofloxacin + Ornidazole $+\alpha$-Tocopherol (Lenovo AP; Intas Pharmaceuticals-vet) intra-uterine infusion for three consecutive days of the estrus and AI was performed on the next estrus, resulted conception of $35 \%$ animals in two inseminations. Cytobrush technique was observed useful in differentiating subclinical endometritis in the repeat breeding cows and Levofloxacin + Ornidazole $+\alpha$-Tocopherol (Lenovo AP) treatment was satisfactory in the cows showing turbid mucus discharge.
\end{abstract}

Keywords: Crossbred cows, repeat breeding, cytobrush, endometrial cytology, PMN cells

Repeat breeding is a commonly observed problem in the dairy cattle with the reported prevalence rate of $10-14 \%$ (Yusuf et al., 2010). Various causes of repeat breeding include deficiencies of nutrition, hormonal imbalances, anatomical defects, and inflammatory conditions of the genital tract (Raval et al., 2018). Clinical endometritis is a distinct condition and presents purulent vaginal discharge, while mild inflammations of the endometrium have no clinical symptoms and may be responsible for the subfertile condition of the cows. Endometrial cell cytology combined with cervical mucus evaluation is considered effective laboratory tool for predicting uterine health in the repeat breeding cows
(Rangnekar et al., 2002). Diagnosis of subclinical endometritis will differentiate cows to select for the suitable effective treatment. The present exploration on endometrial cytology in the crossbred cows, records the incidence of subclinical endometritis in the normal cyclic and repeat breeding cows and effective treatment of endometritis by Levofloxacin + Ornidazole $+\alpha$-Tocopherol combination uterine infusion.

\footnotetext{
How to cite this article: Pandey, A.K., Sharma, U. and Kumar, S. (2020). Endometrial Cytological Evaluations in Repeat Breeding Crossbred Cows. Theriogenology Insight: An International Journal of Reproduction of Animals, 10(2): 31-34.
}

Source of Support: DBT, GOI; Conflict of Interest: None 


\section{MATERIALS AND METHODS}

The presented work was carried during the month of June, 2018 to Jan 2020 on 80 crossbred cows presented in the veterinary clinics, dairy farms and in the nearby villages of R.S. Pura, Jammu. Collection and evaluation of cervico-vaginal mucus (CVM) samples from the cervix/ vaginal fornix during estrus were performed on aspirated mucus using sterilized insemination gun sheath used as a pipette connected to a $10 \mathrm{ml}$ syringe. After collection, CVM samples were assessed for the transparency and presence of push flakes and were categorized as clear stringy and turbid with white flakes (Bhat et al., 2015). Cytological samples were collected for the estrus cows using modified cytobrush attached to stainless steel insemination gun covered with plastic sheath (Fig. 1).

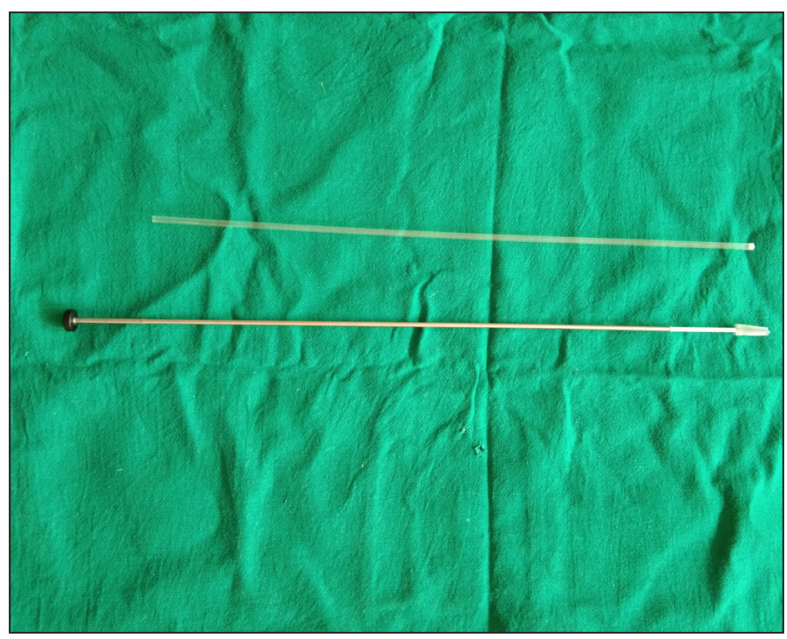

Fig. 1: Modified cytobrush attached to AI gun barrel

Cytobrush with a cut stem tip of about $5 \mathrm{~cm}$ was attached tightly in a plunger free AI gun with the help of a small piece of paper in between to make the diameter of cytobrush fit in the AI gun. Insemination gun sheath with widened tip end free of nozzle was used to cover the cytobrush assembly. Extra sanitary sheath was used to protect the assembly from contamination while inserting in the vagina. After passing the gun through the cervix up to the body of uterus, the cytobrush was pushed out of the sheath covering and was rotated clockwise for one complete rotation while pressing it against the wall of the uterus. The cytobrush was removed in concealed position covered in the sheath from the vagina and was smeared on a clean microscopic glass slide by rolling the cytobrush tip.
The slides were fixed with $100 \%$ methanol for 3 minutes and were stained using Giemsa stain for 30 minutes. Observations were made under compound microscope (40 X). About 100-200 endometrial and PMN cells were counted in each sample and the number of polymorpho nuclear cells percentage in relation to the total cells counted in the slides were estimated (Fig. 2). The subclinical endometritis was declared in repeat breeding cows on the basis of clear CVM and > 4 \% PMN cells (Singh et al., 2016). One way ANOVA was used for determination of statistical significance between the groups on the PMN cell \%.

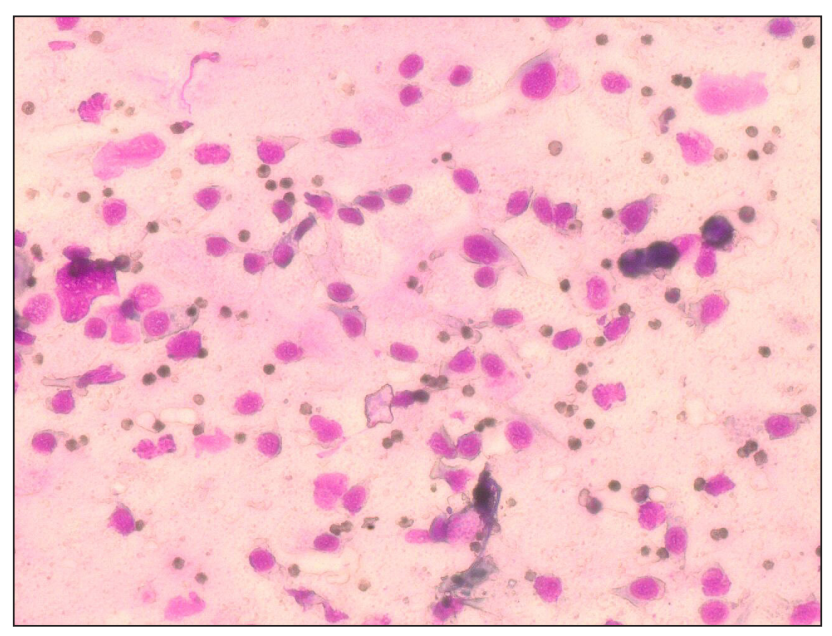

Fig. 2: Giemsa stained cytological smear (40X Olympus)

\section{RESULTS AND DISCUSSION}

The mean PMN cell \% of the cows in the three groups were, $2.01 \pm 0.25,5.36 \pm 0.39,11.82 \pm 0.82$ in the normal cyclic, repeat breeding and endometritis cows. There was significant difference in the percentage of mean PMN cells in the three groups which indicated diagnostic use of PMN cell count in this experiment. Cytobrush technique is the best technique for obtaining uterine cytology samples in the cows compared to the other described techniques as there is no cell distortion (Kasimanickam et al., 2004). Endometrial cytology could be used for differentiating animals having genital infections and for prompt decision making for treating such animals (Raval et al., 2018).

The cytological thresh hold values for the diagnosis of subclinical endometritis varies with the postpartum interval (Chapwanaya, 2008). Here the animals having $>4 \%$ PMN cells were $1(5 \%)$, 
Table 1: Endometrial cytological evaluations using cytobrush technique in normal cyclic and repeat breeding crossbred cows

\begin{tabular}{|c|c|c|c|c|c|c|c|c|}
\hline \multirow{2}{*}{ Groups } & \multirow{2}{*}{$\begin{array}{l}\text { Cervical mucus } \\
\text { quality }\end{array}$} & \multirow{2}{*}{$\begin{array}{l}\text { PMN cell \% } \\
\text { (Mean SE) }\end{array}$} & \multirow{2}{*}{$\begin{array}{l}\text { Animals } \\
\text { having }>4 \% \\
\text { PMN cells (\%) }\end{array}$} & \multirow{2}{*}{$\begin{array}{l}\text { Animals } \\
\text { having }>8 \% \\
\text { PMN cells }(\%)\end{array}$} & \multicolumn{4}{|c|}{ Animals conceived } \\
\hline & & & & & $\mathbf{I}^{\text {st }} \mathbf{A I}$ & $\mathrm{II}^{\text {nd }} \mathrm{AI}$ & $\mathrm{III}^{\mathrm{rd}} \mathrm{AI}$ & Total \\
\hline $\begin{array}{l}\text { Normal cyclic } \\
\text { cows }(n=20)\end{array}$ & $\begin{array}{l}\text { Clear stringy } \\
\text { mucus }\end{array}$ & $2.01 \pm 0.25^{\mathrm{a}}$ & $1(5 \%)$ & $0(0 \%)$ & $7(35 \%)$ & $7(35 \%)$ & $5(25 \%)$ & $19(95 \%)$ \\
\hline $\begin{array}{l}\text { Repeat breeding } \\
\text { cows }(n=40)\end{array}$ & $\begin{array}{l}\text { Clear stringy } \\
\text { mucus }\end{array}$ & $5.36 \pm 0.40^{\mathrm{b}}$ & $26(65 \%)$ & $6(15 \%)$ & $1(2.5 \%)$ & $2(5 \%)$ & $1(2.5 \%)$ & $4(10 \%)$ \\
\hline $\begin{array}{l}\text { Endometritis } \\
\text { cows }(\mathrm{n}=20)\end{array}$ & $\begin{array}{l}\text { Turbid mucus } \\
\text { with white flakes }\end{array}$ & $11.82 \pm 0.82^{c}$ & $20(100 \%)$ & $18(90 \%)$ & - & $4(20 \%)$ & $3(15 \%)$ & $7(35 \%)$ \\
\hline
\end{tabular}

Means bearing different superscripts $(a, b, c)$ within column differ significantly $(p<0.05)$.

26(65\%), 20(100\%) while animals having $>8 \%$ PMN cells were $0(0 \%), 6(15 \%)$ and $18(90 \%)$, respectively in the normal cyclic, repeat breeding cows and endometritis group of cows (Table 1). Chapwanaya (2008) reported threshold of more than $8 \%$ PMN cell at 150 postpartum days in cows. Dimitrov et al. (2016) observed high correlation with the pregnancy rate on PMN cell \% on $8 \%$ threshold level.

The percent cows $(n)$ conceived after $1^{\text {st }}, 2^{\text {nd }}$ and $3^{\text {rd }}$ inseminations in the normal cyclic cows were $35 \%(7), 35 \%(7)$ and $25 \%(5)$ while in the repeat breeding group it was $2.5 \%(1), 5 \%(2)$ and $2.5 \%$ (1) respectively. Here the conception rates of the cows are from the small holder dairy farmers of the same geographical location, though possible variations may exist due to suckling status, age, parity and general body condition score (Khan et al., 2015). The overall conception rate in normal cyclic groups was 95\% after 3 inseminations while in the repeat breeding group 10\% cows conceived indicating other reasons of the repeat breeding problems (Chapwanaya, 2008).

Cows with turbid discharge were given $20 \mathrm{ml}$ liquid Levofloxacin + Ornidazole $+\alpha$-Tocopherol (Lenovo AP; Intas Pharmaceuticals-vet) intra-uterine infusion for three consecutive days on estrus and AI was performed on the next estrus. The treated cows conceived at first and second AI were $20 \%$ and $15 \%$ in the two consecutive inseminations counting total conception rate of $35 \%$ in this group (Table 1). Present study indicates that, Levofloxacin + Ornidazole + $\alpha$-Tocopherol combination may effectively be used to treat endometritis condition in crossbred cows. This might be due to strong antioxidant property of $\alpha$-Tocopherol and bactericidal action of Levofloxacin (Mishra et al., 2018).

\section{CONCLUSION}

It was concluded form the study that modified cytobrush technique is effective method of endometrial cytology sample collection and differentiation of uterine condition based on PMN cell percent. The intra uterine treatment of Levofloxacin + Ornidazole $+\alpha$-Tocopherol combination may be recommended to relieve clinical endometritis in cows.

\section{ACKNOWLEDGEMENTS}

We are thankful to the Department of Biotechnology, Govt. of India for the financial support under DBTFoldscope project.

\section{REFERENCES}

Bhat, F.A., Bhattacharyya, H.K., Fazili, M.R., Hussain, S.A. and Khan, M.Z. 2015. Studies on estrual cervical mucus of repeat breeding cows with special reference to ovulatory disturbances and genital infection. Theriogenology, 5(2): 113-23.

Chapwanaya, C. 2008. Uterine disease in dairy cows: Classification, diagnosis and key roles for veterinarians. Irish Veterinary Journal, 61(3): 183-186.

Dimitrov, D., Manov, V., Ralchev, I., Hristov, K and Popov, G. 2016. Cytological characteristics of endometritis in dairy cattle. Tradition and Modernity in Veterinary Medicine, 1(1): 27-32.

Kasimanickam, R., Duffield, T.F., Foster, R.A., Gartley, C.J., Leslie, K.E., Walton, J.S. and Johnson, W.H. 2004. Endometrial cytology and ultrasonography for the detection of subclinical endometritis in postpartum dairy cows. Theriogenology, 62:9-23.

Khan, M.R.K., Uddin, J. and Gofur M.R. 2015. Effect of age, parity and breed on conception rate and number of service per conception in artificially inseminated cows. Bangladesh Livestock Journal, 1: 1-4. 
Mishra, S., Sahu, S.K., Panigrahi, S., Biswal, S.S., Mishra, S.R., Ranjan, R., Mohanty, D.N., Pattnaik, B. and Das, S. 2018. Comparative therapeutic efficacy of levofloxacin, ornidazole and alpha tocopherol combination with prostaglandin F2 $\alpha$ on IL- 6 and IL-10 transcript level in longstanding cases of endometritis in crossbreed Jersey cows. Iranian Journal of Veterinary Research, 19(3): 217-224.

Rangnekar, M.M., Dhoble, R.L., Gacche, M.G., Ingawale, M.V., Sawale, A.G. and Jadav, J.M. 2002. Physical properties of estrual cervical mucus in repeat breeding HF crossbred cows with reference to fertility. Indian Journal of Animal Sciences, 72(12): 1122-24.

Raval, S.R., Panchal, M.T. Dhami, A.J. and Parmar S.C. 2018. Endometrial Cytology and Cervical Mucus Characteristics of Repeat Breeding Crossbred Cows in Relation to PostTreatment Fertility. The Indian Journal of Veterinary Sciences E Biotechnology, 13(4): 26-31.
Singh, J., Honparkhe, M., Chandra, M., Kumar, A., Ghuman, S.P.S. and Dhindsa, S.S. 2016. Diagnostic efficacy of uterine cytobrush technique for subclinical endometritis in crossbred dairy cattle. Indian Veterinary Journal, 93(2): 11-13.

Yusuf, M., Nakao, T., Ranasinghe, R.B.K., Gautam, G., Long, S.T. and Yoshida, C. 2010. Reproductive performance of repeat breeders in dairy herds. Theriogenology, 73: 12201229. 